University of Nebraska - Lincoln

DigitalCommons@University of Nebraska - Lincoln

2017

\title{
A Review of Women's Leadership Conferences: Ways Public Research Institutions Support Female Students Opting-In
}

Tania Reis

Gannon University, reis001@gannon.edu

Marilyn L. Grady

University of Nebraska-Lincoln, mgrady1@unl.edu

Follow this and additional works at: https://digitalcommons.unl.edu/jwel

Part of the Educational Administration and Supervision Commons

Reis, Tania and Grady, Marilyn L., "A Review of Women's Leadership Conferences: Ways Public Research Institutions Support Female Students Opting-In" (2017). Journal of Women in Educational Leadership. 210.

https://digitalcommons.unl.edu/jwel/210

This Article is brought to you for free and open access by the Educational Administration, Department of at DigitalCommons@University of Nebraska - Lincoln. It has been accepted for inclusion in Journal of Women in Educational Leadership by an authorized administrator of DigitalCommons@University of Nebraska - Lincoln. 


\title{
A Review of Women's Leadership Conferences: Ways Public Research Institutions Support Female Students Opting-In
}

\author{
Tania Carlson Reis \\ Gannon University \\ Marilyn L. Grady \\ University of Nebraska-Lincoln
}

\begin{abstract}
The purpose of this report is to provide an overview of women's leadership conferences at public research universities. A search of the 2015 Carnegie Classification of Institutes of Higher Education revealed a list of 157 research universities. Of these institutions, 40 held a women's leadership conference. Implications are discussed in how a women's leadership conference supports female students opting-in.
\end{abstract}

The story of women and leadership is complicated. According to Eagly and Carli (2007a,b), women are finding their way to leadership positions. A complex labyrinth has replaced absolute barriers, and women exhibit creative and resourceful strategies in navigating a non-linear leadership path (Eagly \& Carli, 2007a,b). Although women remain significantly underrepresented in top leadership positions, the labyrinth Eagly and Carli described remains a metaphor of explanation. 
Issues associated with women's persistence toward leadership positions begin in the sociological beliefs of a woman's role and the responsibilities of work and family (Carli \& Eagly, 2007; Eagly \& Carli, 2007a; Keohane, 2007). Women, regardless of marriage or status, remain closely linked to biased views of work capacity. For example, women are not expected to be the sole source of financial support within a family; and thus, they are perceived to not require the salary that a male peer earns. Women are viewed as the primary caregiver to children; and thus, they may be given less responsibility due to the perception a woman has less time to commit to work-related projects. The bias associated with role congruity (Eagly \& Karau, 2010), and how role expectations define the boundaries of a woman's world, contribute to an overriding shadow on how women's work is interpreted and rewarded in the leadership domain.

The definition of gender and societal roles have changed (Eagly \& Carli, 2007a; Rhode \& Kellerman, 2007). Men and women share household duties and childcare. The firm boundaries of gender roles are bending. As women's educational qualifications increase, their presence in leadership positions increases. In 2016, women represented $50.8 \%$ of the United States population and earned more than half of all bachelor's, master's and doctoral degrees (Catalyst, 2016). Women comprise nearly half the workforce and make-up $36.4 \%$ of mid-level management and $\mathbf{2 5 . 1} \%$ of senior management positions (Catalyst, 2016). The fact that only $4.6 \%$ of women lead S\&P 500 companies lends credence to an understanding of how women are supported within the labyrinth framework and provides an important context for how women sustain their leadership journeys.

\section{Background}

Women benefit from leadership experiences specifically designed to focus on women (Reis, 2015a). These experiences may include leadership training programs or women's leadership conferences. The purpose of bringing women together is not about building a sisterhood (Williams \& Dempsey, 2014); but rather, it is about creating space for women to connect around a purposeful theme: leadership. Research supports the existence of the labyrinth, with multiple barriers, stops and starts, as the path for women to leadership positions (Eagly \& Carli, 2007a,b,). However, each time a woman negotiates a barrier, this action does not 
clear the path or widen the road to opportunity. For women, negotiating barriers is constant and part of how women move forward (Reis, $2015, b)$. Women's leadership conferences offer a platform for ideas and exchange of information about the ways women move past these barriers and how they persist to make it to the top.

Discussion of the ways gender intersects with student leadership is an important higher education topic as well. The lived experiences of a student inform his or her lens on leadership. For female students, leadership development involves sustained support as they move from an environment of academic freedom to the realities of work and career life. The shock of what a female student dreamed she would become and the realization of bias in salary and opportunity can leave her stranded in the labyrinth.

Leadership programs are more successful for undergraduate women when they incorporate a communal environment that supports feminist thinking (Shim, 2013). Interestingly, undergraduate women report having a higher degree of leadership skills than male students; yet, male undergraduates report a higher degree of self-confidence in their leadership abilities than female undergraduates report (Dugan \& Komives, 2007). Female students exhibit a higher degree of competency in leadership but less confidence in their ability to exercise these skills. Although effect sizes were small, the findings by Dugan and Komives (2007) supported the need for gender-specific leadership conferences. Conferences serve as places for students to connect and negotiate big ideas. Conferences are places to showcase talent, and allow participants to learn from the lived experiences of others. As female students move forward in their leadership journeys, it makes sense that the strength of skill and lower self-confidence will develop congruently in the process.

Gender remains a pivotal concept within the framework of leadership development. The focus on women and women's leadership remains congruent between education and professional practice. The same supporting opportunities for women in business and career can support women in undergraduate and graduate education. The same question of ways women opt-in (Barnett, 2007; Ward \& Wolf-Wendel, 2012) to careers and leadership are evident in higher education and professional practice.

The purpose of this report is to provide an overview of women's leadership conferences at public research universities in the U.S. Women's leadership conferences provide support and opportunities for 
women to meet with professional colleagues and experience events focused on leadership. The public research universities that provide women's leadership conferences for students are cited; and, how conferences may contribute to women's leadership development are presented

\section{Methodology}

Data were collected via the Internet through a systematic search (Creswell, 2014) guided by the research question: Which public research universities hold women's leadership conferences? To identify public research universities, I consulted the 2015 Carnegie Classification of Institutes of Higher Education. I selected Basic Descriptors and created a list of all universities in the categories of Research University: Highest and Research University: Higher. This list included 222 research institutions. Of these universities, 157 were public and 65 were private. Data collection was focused on the 157 public research universities.

I completed a search of each of the 157 public university websites using the search terms "leadership conference" and "women's leadership conference." In addition to the name of the university, data were collected and coded for the following categories:

Year: Conferences held in academic years 2014-2015, 2015-2016, and 2016-2017.

Cost: Were participants required to pay to attend?

Gender Affiliation: Was the conference directed toward females, males or both genders?

Target Population: Was the conference open to undergraduate, graduate, or both student

populations?

Date: Date of most recent conference as reported on the website.

Website: Collection of the website address.

Notes: This category included all memos from the university websites that indicated specific details about the conferences. For example, some conferences were noted to be the $3^{\text {rd }}$ or $10^{\text {th }}$ annual conference. Others were noted to be inaugural conferences. Other memos 
indicated whether the conference was directed toward a specific race/ethnicity or study specialty, such as business or law.

\section{Validity and Reliability}

Data collection was validated through audit and review. To ensure that I had searched each university's website accurately, I divided the list of 157 universities between three graduate students. Each student completed a search of the institutions assigned. In order to ensure the data collected were congruent, we engaged in peer review and debriefing (Creswell, 2013). We met formally to assign definitions of the search terms and boundaries of the study.

I compared the results of my data collection from all 157 universities' websites to data collected by the three students. This allowed me to increase clarification of the descriptors and write additional memos specific to each program. The data gathered remained congruent. This cross-comparison increased the reliability of the findings.

\section{Findings}

Findings indicated that of the 157 public research universities listed in the 2015 Carnegie Classification of Institutes of Higher Education, 106 held a leadership conference. Of the 106 conferences, 40 were directed toward women at the undergraduate or graduate level. Of the 157 public research universities in the highest and higher research category, $40(24.47 \%)$ held a women's leadership conference focused on female students.

Of the 40 women's conferences, 13 were sponsored by the college of business or programs in public policy. Twenty women's conferences were sponsored by departments of student affairs, alumni associations, education colleges, communication, and campus women's centers. Of those 20 , two conferences were joint efforts between university women's centers and the college of business or division of student affairs. Seven conferences were university sponsored. One conference was a joint effort between institutions. Ohio University and Cleveland State University jointly sponsor the Women's Leadership Symposium. The conference is supported by each institution's alumni association and is open to female students at both schools. 
Table 1. Universities that Held a Women's Leadership Conference for Academic Years* 2014, 2015 and 2016

\begin{tabular}{|c|c|c|c|}
\hline Name of University & rraduate/Both F & Fee for $\mathrm{S}$ & Website \\
\hline Auburn University & Both & Yes & www.auburn.edu \\
\hline Bowling Green State University & Undergraduate & No & www.bgsu.edu \\
\hline Cleveland State University & Both & Yes & www.csuohio.edu \\
\hline Clemson University & Both & Yes & www.clemson.edu \\
\hline Florida International University & Both & No & www.fiu.edu \\
\hline Florida State University & Both & No & www.fsu.edu \\
\hline Georgia Institute of Technology & Both & Yes & www.gatech.edu \\
\hline Georgia State University & Both & Yes & www.gsu.edu \\
\hline Kent State University & Both & No & www.kent.edu \\
\hline Louisiana State University & Both & No & www.lsu.edu \\
\hline Miami University of Ohio & Both & No & www.miamioh.edu \\
\hline Michigan State University & Both & Yes & www.msu.edu \\
\hline North Carolina State University & Graduate & Yes & www.ncsu.edu \\
\hline Northern Arizona University & Both & No & www.nau.edu \\
\hline Ohio University & Both & Yes & www.ohio.edu \\
\hline Oklahoma State University & Both & Yes & www.okstate.edu \\
\hline $\begin{array}{l}\text { Pennsylvania State University - } \\
\text { Main Campus }\end{array}$ & Both & No & www.psu.edu \\
\hline Rutgers University & Graduate & No & www.rutgers.edu \\
\hline $\begin{array}{l}\text { Southern Illinois State University } \\
\text { Carbondale }\end{array}$ & Both & No & www.siu.edu \\
\hline University of Arkansas & Both & Yes & www.uark.edu \\
\hline University of California - Berkeley & Both & Yes & www.berkeley.edu \\
\hline University of California - Los Angeles & Graduate & Yes & www.ucla.edu \\
\hline University of California - Santa Barbara & Both & Yes & www.ucsb.edu \\
\hline University of Central Florida & Both & Yes & www.ucf.edu \\
\hline University of Colorado Boulder & Undergraduate & Yes & www.colorado.edu \\
\hline University of Idaho & Both & No & www.uidaho.edu \\
\hline University of Kansas & Both & Yes & www.ku.edu \\
\hline University of Louisville & Both & Yes & www.louisville.edu \\
\hline University of Massachusetts - Amherst & Undergraduate & No & www.umass.edu \\
\hline University of Massachusetts - Lowell & Both & No & www.uml.edu \\
\hline University of Michigan & Both & Yes & www.umich.edu \\
\hline University of Missouri-Columbia & Both & Yes & www.missouri.edu \\
\hline University of Nebraska Lincoln & Both & Yes & www.unl.edu \\
\hline $\begin{array}{l}\text { University of Oklahoma - } \\
\text { Norman Campus }\end{array}$ & Both & Yes & www.ou.edu \\
\hline University of Pittsburgh & Both & Yes & www.pitt.edu \\
\hline University of Rhode Island & Both & No & www.uri.edu \\
\hline University of South Carolina & Both & No & www.sc.edu \\
\hline University of Texas at Arlington & Both & Yes & www.uta.edu \\
\hline University of Texas at Austin & Graduate & Yes & www.utexas.edu \\
\hline University of Utah & Undergraduate & Yes & www.utah.edu \\
\hline
\end{tabular}

\footnotetext{
*Academic Year is defined as beginning in August/September and ending in April/May.
} 
There were similarities in the structure of the 40 conferences. Thirty-five (88\%) of the conferences provided opportunities for pre or post networking and conversation. Three of the conferences offered a pre-conference dinner the night before to lead up to the event. All of the 40 conferences were scheduled between 8:00 a.m. and 5:00 p.m. Each of the 40 conferences featured a keynote speaker. Each conference included a series of break-out sessions or different speakers. Participants could choose to attend sessions on specific topics or issues of personal interest.

Thirty-eight of the universities described the conferences as preplanned events. Attendees were the audience for the information and events created by the conference planning committee.

Three institutions, University of Nebraska-Lincoln, University of Missouri, and University of Idaho issued calls for proposals to present scholarly research or contemporary issues for conference break-out sessions. The University of Nebraska-Lincoln uses an online proposal submission process with peer review. University of Missouri and University of Idaho issue a call for program proposals that are reviewed by the conference executive committee. Although other women's conferences may elicit student participation in different ways, only these three universities actively solicited student research presentations in addition to proposals from other scholars and leaders.

Conference registration fees were noted in the coding categories. A review of the fees for attendance at each university's conference revealed that 25 institutions required payment and 15 were advertised as free for students. However, the fee structure was different for each of the 40 conferences. Seven universities offered a reduced registration fee for students and a higher registration fee for non-students, faculty and community members. Alumni were given a reduced rate at three institutions. Two conferences were free or reduced fees for a student studying in a specific college or for a student involved in a specific club that sponsored the conference.

Three conferences were underwritten by a grant from a donor, organization, or company. The highest conference fee recorded for students was $\$ 295$ dollars. Scholarship opportunities were noted on the websites of $20(50 \%)$ of the conferences that charged fees. However, it was not possible based on the website information to determine if the scholarship was offered by the conference or if a student was being directed to apply for other funds available to students at the universities. 
None of the conference websites specified that men could not attend the conferences. Some of the websites noted that men were welcome to attend. The 40 websites were consistent in the emphasis on the theme of women's leadership. Although the 40 conferences were connected to specific institutions, it was not possible to determine the geographic reach of the conference. Information about conference attendees and attendance was not available through an examination of the website information.

\section{Conclusion}

The purpose of this report was to provide an overview of women's leadership conferences at public research institutions. Findings indicate that $40(24.47 \%)$ of public research universities hold women's leadership conferences. Viewed in isolation, it is difficult to understand the significance of that number. However, setting the data in the context of women in leadership, and the ways women opt-in to leadership roles and navigate complicated leadership journeys, gives meaning to the $24.47 \%$ number.

Ward and Wolf-Wendel (2012) described the element of personal choice as it is understood for women. Women are viewed as optingin or opting-out of career decisions. The agency of choice lies with the individual woman. If a woman chooses to take a leadership position, she is opting-in. If she chooses not to take a leadership position, she is opting-out. Corporate conversations about family-friendly work practices or bias in salary and promotion are ignored. By focusing on a woman's choice, the company's hands are clean.

Confirming stereotypes that men are natural born leaders and women can learn to be leaders, complicates the decisions women make to opt-in (Barnett, 2007). Although women comprise half of the workforce, opting-in to leadership is a lonely pursuit. Women who lead often are viewed as getting their positions by chance versus hard-work. Women who lead a successful project or save a company substantial money are perceived to be lucky (Williams \& Dempsey, 2012). For women, one success is not enough to be recognized as successful. Repeated successes are necessary before a woman's work is acknowledged. Vertical promotion in an organization is not an easy path for women. This is the reason for the labyrinth. 
The story of women's challenges to leadership is not a new story. The sociological foundations that support the labyrinth theory are slow to change (Eagly \& Carli, 2007a). However, research has shown that for women, opting-out has serious consequences (Ward \& Wolf-Wendel, 2012). At the micro level, women who opt-out may experience a personal and financial loss. This loss is capitalized the longer she avoids increased responsibility or higher paying jobs. At the corporate level, the lack of women moving into leadership positions reaffirms the incorrect belief that opting-out is a choice. Companies are freed from having to negotiate with women on policy and environmental factors that come from a diverse workforce.

Women students in higher education graduate to jobs in which leadership can be elusive. They may be asked to function within an unfamiliar world filled with challenges and barriers to advancement. Regardless of the process, it is imperative that women opt-in, not optout of, the leadership labyrinth. Leadership is learned and reflects the combination of multiple experiences. Women's leadership conferences can assist and support women as they prepare for their leadership journeys.

\section{References}

Barnett, R. C. (2007). Women, leadership, and the natural order. In B. Kellerman \& D. L. Rhode (Eds.), Women and leadership: The state of play and strategies for change (pp. 149-174). San Francisco, CA: Jossey-Bass.

Carli, L. L., \& Eagly, A. H. (2007). Overcoming resistance to women leaders: The importance of leadership style. In B. Kellerman \& D. L. Rhode (Eds.), Women and leadership: The state of play and strategies for change (pp. 127148). San Francisco, CA: Jossey-Bass.

Creswell, J. W. (2013). Qualitative inquiry and research design: Choosing among five approaches. Los Angeles, CA: SAGE.

Dugan, J. P., \& Komives, S. R. (2007). Developing leadership capacity in college students: Findings from a national study. A Report from the MultiInstitutional Study of Leadership, College Park, MD: National Clearinghouse for Leadership Programs.

Eagly, A. H., \& Carli, L. L. (2007a). Through the labyrinth: The truth about how women become leaders. Boston, MA: Harvard Business School Press.

Eagly, A. H., \& Carli, L. L. (2007b). Women and the labyrinth of leadership. Harvard Business Review. 9, 63-71. 
Eagly A. H., \& Karau, S. J. (2002). Role congruity theory of prejudice toward female leaders. Psychological Review, 109(3), 573-598.

Keohane, N. O. (2007). Crossing the bridge: Reflections on women and leadership. In B. Kellerman \& D. L. Rhode (Eds.), Women and leadership: The state of play and strategies for change (pp. 65-91). San Francisco, CA: Jossey-Bass.

Reis, T. C. (2015a). Leadership stories: Defining gender in university leadership. Journal of Women in Educational Leadership, Paper 70.

Reis, T. C. (2015b). Leadership traits of successful women university presidents: A qualitative study (Doctoral dissertation). Retrieved from ProQuest Dissertation Publishing (UNL 12707).

Rhode, D. L., \& Kellerman, B. (2007). Women and leadership. In B. Kellerman \& D. L. Rhode (Eds.), Women and leadership (pp. 1-62). San Francisco, CA: Jossey-Bass.

Ward, K., \& Wolf-Wendel, L. (2012). Academic motherhood: How faculty manage work and family. Rutgers, NJ: Rutgers University Press.

Williams, J. C., \& Dempsey, R. (2014). What works for women at work: Four patterns working women need to know. New York: NYU Press. 